\title{
The British Trade Unions and Europe
}

Les syndicats britanniques et l'Europe

John Monks

\section{OpenEdition}

\section{Journals}

Electronic version

URL: http://journals.openedition.org/rfcb/1146

DOI: $10.4000 /$ rfcb. 1146

ISSN: 2429-4373

\section{Publisher}

CRECIB - Centre de recherche et d'études en civilisation britannique

\section{Printed version}

Date of publication: 27 July 2009

Number of pages: $153-165$

ISBN: 978-2-9115-8028-4

ISSN: 0248-9015

Electronic reference

John Monks, «The British Trade Unions and Europe », Revue Française de Civilisation Britannique [Online], XV-2 | 2009, Online since 01 November 2016, connection on 01 May 2019. URL : http:// journals.openedition.org/rfcb/1146 ; DOI : 10.4000/rfcb.1146

\section{c) (i) $\odot$}

Revue française de civilisation britannique est mis à disposition selon les termes de la licence Creative Commons Attribution - Pas d'Utilisation Commerciale - Pas de Modification 4.0 International. 


\title{
The British Trade Unions and Europe
}

\author{
John MONKS \\ General Secretary of the European Trade Union Confederation
}

The world is undergoing a period of rapid, precipitate change. At the time of writing, President Barack Obama has just been elected while it is clear that we are entering a serious world-wide recession, a recession born in the USA but to a degree also in the European Union (whose banks bought one third of the 'toxic' American investments). Some people speak of 1929 (the Wall Street crash), others of 1931 (the low point of the Great Depression), while some left wing commentators make the comparison with 1989, the collapse of the Soviet system. One thing is for sure. Things will never be the same again.

Since the collapse of communism under its own internal contradictions, capital has had the whole world, more or less, at its feet. It could go most places seeking the best returns. It was afraid of nothing - there was no competing system which threatened its expropriation. This struck home to me vividly when Bill Clinton visited Vietnam towards the end of his Presidency. You won the war, observed Clinton wryly, but, now, to survive, you are observing the rules of world capitalism. However, in September 2008, the world rocked again. US Treasury Secretary Paulson and Federal Reserve Chairman Bernanke went cap in hand - or in Hank Paulson's case on bended knee - to the US Congress for $\$ 700$ billion to prevent the meltdown of Wall Street. We could say that capitalism, once again, seems rent by its own internal contradictions, and we fear this might be as serious as it was in 1929. The 2008 deal was not done either, until negotiations had imposed at least some obligations on the Wall Street financiers, to preserve a few interests of the US taxpayers, while bailing out the bankers.

In the EU, the response of mid October was more 'dirigiste'. 'Laissez faire, c'est fini' said President Sarkozy. Such language can be heard throughout Europe and it can only intensify as the fall-out from the EU's $€ 1.8$ trillion bank rescue becomes clearer, and as Europe's elites discover that their own banks are the most leveraged in the world and have played their own Wagnerian part in Götterdämmerung. European and UK banks are five times more exposed to emerging markets than US banks. They alone hold the collective time-bomb of $\$ 1.6$ trillion in hard currency loans to Eastern Europe - now starting to detonate in Hungary, Ukraine, Romania, and even Russia. At some point, Europe will have to face the truth that their own credit bubbles may be just as bad as the excesses of US sub-prime property. As that occurs, the shock will move by degrees from revulsion to political rage. Professor Hobsbawm, who spent his youth watching Hitler's rise in Berlin, has a warning for those who think this will help the Left in any recognizable form. 'In the 1930s, the net political effect of the Depression was to enormously strengthen the Right,' he said. To counter that is the challenge to trade unionism everywhere. 
The European Union, the Eurozone and the European social model were created precisely to pre-empt the threatened collapse into economic depression and war which had convulsed Europe in the 1930s and 1940s and which threatens us now. The British political establishment, an ever sceptical monitor of post-war European developments - to this very day - stuck firmly with its Trans-Atlantic dialogue, loath to support the new social and economic dialogue growing in the heart of Europe. This has been the case also with British trade unions, except for a very significant period, running from a speech by the European Commission President, Jacques Delors, to the TUC Congress in 1988 to the 2007 TUC Congress when the TUC voted to call for a referendum on the draft European Constitutional Treaty - a strongly sceptical signal.

The critical paragraphs in that resolution were:

Congress is also concerned that the competition protocol in the Reform Treaty could be a Trojan horse to promote unfettered privatisation throughout the EU. Congress is bitterly disappointed that the Charter of Fundamental Rights will not apply to British workers and their trade unions and calls on the Government to show commitment to Europe's social dimension as this is necessary for British trade unions' support for the future development of Europe. ${ }^{1}$

These paragraphs reflected a growing euroscepticism and reawakened old concerns on the left about 'the bosses' Europe' and the will to preserve British-style 'free collective bargaining', despite the battering it had received from Mrs Thatcher through anti-trade union laws since 1979. Of course, the bitterness is entirely understandable with which British unions watched former Prime Minister Tony Blair plead with other Member States in the Treaty negotiations, threaten them with a veto of the whole Treaty and finally block the extension of the Charter of Fundamental Rights to British workers.

This paper seeks to explain to those interested observers in the rest of Europe, who have been struggling to understand quite how British trade unions got from A to Z. Yet we know that politics very rarely moves in a straight line. This is most clearly observed by the actions of that great American Socialist President, George W. Bush, who nationalised the commanding heights of the US economy, to be chased along behind in the sweepstake race by the rather neo-liberal former Chancellor of the Exchequer, Gordon Brown, UK Prime Minister, in partnationalising very large banks. I have to shake myself on recalling that it used to be the Workers Revolutionary Party and other Trotskyite sects which used to call for the nationalisation of the banks standing on pavements outside TUC Congresses. I used to dismiss their arguments summarily!

For a very long period of time British trade unions did not like the way things were done across the Channel. They preferred their own way of doing things, which had evolved steadily throughout the rough and tough course of the industrial revolution. They liked to think that unions, like cricket, golf and football, had been

${ }^{1}$ TUC Annual Report 2007. 
invented in Britain. They did not like the German model of co-determination which was regarded as too collaborative and they did not see much merit in the emerging European Union. The central ideological battle within unions was centred on Eastern Europe and the attitude to the Soviet Union.

The following period is the 'Delorean' phase. It has lasted around 20 years. It was actually created by Mrs Thatcher. Trade unions, as we all know so well are reactionary (in the literal sense of the word) organisations. We tend to react to circumstances rather than deal in a pro-active manner. In 1988 we did the same - we reacted to the greatest enemy we had experienced from the other side of class war UK politics, Mrs Thatcher, by supporting her chief ideological opponent - President Jacques Delors, the French socialist and trade unionist. Mrs Thatcher hated Social Europe with a passion she had previously reserved only for the Argentine military and the National Union of Mineworkers. What may have irritated Mrs Thatcher so much was the fact that at that famous Congress we broke spontaneously into a strange rendition of 'Frère Jacques' while we gave him a standing ovation. Ron Todd, the late General Secretary of the normally Europe-hostile Transport and General Workers Union had given his blessing: 'Europe,' he said, as a man who should have known, 'is the only card game in town!'

The present period is one of bruised resentment. This resentment is mixed with bad feelings about European developments, some of which have been promoted by the British Labour Party leadership, consistently, for 11 years, despite the fact that those main trade unions remain that Party's chief funders. This is the age of contradiction returned with a vengeance. I would like to begin with the second period and use that to bring some light to bear on the first period and hopefully on the third period. Then I will end by expressing my wish for a fourth period when Europe and the unions are reconciled to each other. We are far from that (for me) happy state at present but it must be the best goal for workers.

\section{A comprehensive framework of rights}

Where have many of the most significant advances for British working people in recent years come from? The answer is Europe. Why Europe? Chiefly because economic integration necessitates a Europe-wide means of addressing its structural and social consequences. It is the trade union movement that has in every case driven the campaign for what Jacques Delors called 'collective bargaining at a higher level'. These agreements have increasingly been translated into national and local collective agreements as well as individually applied rights at national level in Britain and elsewhere in the EU. The rights and obligations shared by trade unions, workers and employers provide a platform for future advances. Members right across the trade union movement have already benefited.

The EU social dimension has produced a lot for people at work. Too few people in Britain are aware of the twelve rights listed in an excellent TUC booklet published in 2006, Europe and Your Rights at Work, based on EU law. This booklet, which provides illustrated examples of these twelve rights, was written jointly by Lord David Lea, former TUC Assistant General Secretary and Stephen Hughes, the Labour Euro MP for Durham and long time friend of the ETUC. European social 
measures, introduced since Britain joined the European Community in 1973, have improved the quality of all workers' contracts of employment in the United Kingdom.

The twelve main areas of EU law applied in the UK are as follows:

- equal pay for women

- outlaw discrimination on grounds of sex

- protection of acquired rights

- maternity and paternity rights

- equality for part-time workers

- equality for fixed term workers

- four weeks minimum paid holidays

- limits on the working hours each week

- protection against redundancy

- information and consultation rights

- European Works Councils

- health and safety rights.

The late Professor Brian Bercusson of Kings College, London, and former inspirational legal adviser to the ETUC, never hesitated in pointing out the origins of these worker rights in European labour law. Running right through the list, as a central theme, is the importance of bringing forward women's rights at work and more recently vital anti-discrimination measures on racial and age discrimination. This framework of law is particularly important for women, guaranteeing, as it does, equal pay for work of equal value and protection from sexual discrimination. Equality and anti-discrimination laws also help deliver a better work/life balance. Maternity rights, extending now to the linked right to parental leave for fathers and for those adopting children, exemplify this principle. This has an impact, too, on the groups of workers who previously did not have pro rata rights with full-time workers and this is best illustrated by the directives on rights for part-time workers. And continuing the theme of family friendly policies, every worker in Britain is now entitled to four weeks' paid holiday every year - with bank holidays soon to be on top.

Looking to other groups of rights, improvements in health and safety rules are a fundamental dimension of the European Union. These have had a very salutary effect on the statistics of death and injury in our workplaces. We illustrate this very broad field in one example that has become iconic, namely the asbestos regulations. Europe also gave birth to protection against dismissal for 'whistle blowing' on health and safety issues which resulted from the 1989 framework directive. The transfer of undertakings directive (TUPE) of 1977 shows that the European dimension has been a real pathfinder for national policy and has not just equalised people's rights at the lowest common denominator. TUPE was an imaginative response to the new development of contracting out and has in recent years been a key protection in the context of privatisation. In the immediate future, this kind of protection is essential for people to adjust and adapt to the challenges posed by India and China and the structural change that globalisation is driving forward. The TUC, the ETUC and Labour MEPs worked very hard to persuade a majority, including the 
British Government, to support the information and consultation of workers directive which only came into force in Britain in April 2005. This requires employers to establish procedures when 10 per cent of workforces formally request an agreement. Several EU directives deal with atypical work - jobs that aren't the traditional full-time, permanent jobs which most employment regulations assume to be the model, but which fewer and fewer people (and a minority of women) actually do. This is an agenda that needs completion - it does not yet cover temporary agency work.

Not all of the EU's benefits for workers result from directives. The European Court of Justice ruled that pensions are part of pay, a decision of huge importance and huge consequences. Some non-discrimination measures have also emerged from the case law of the European Court of Justice. And the UK Employment Relations Act 2004 provision that introduced new rights for trade union members by preventing employers offering them inducements to surrender their rights to collective representation followed the decision of the European Court of Human Rights in the Wilson and Palmer cases (2002). The ECJ can also rule against workers' interests and in favour of economic rights of employers, and this is discussed below. However, EU law can help at the national level. The radical reduction in qualifying periods for protection against unfair dismissal and to qualify for redundancy payments are a result of case law in Britain derived from the EU equal treatment and equal pay directives. Some regulations, far from being handed down by Brussels bureaucrats, have been negotiated under the Social Chapter between the ETUC and the private and public sector European confederations of employers. The list of rights won from the European level is, of course, much longer than this. There are more than 30 specific legal rights - including, for example, protection from discrimination on grounds of religious belief or sexual orientation but the dozen highlighted in the TUC booklet were perhaps the main ones.

\section{The European model of social dialogue}

But it may be asked: could not these measures have been introduced in Britain acting on its own? Well, in some cases which transcend national borders, such as European Works Councils, clearly not. But, even for those measures that hypothetically could have been introduced in Britain unilaterally, not all have been strongly supported by UK governments (of whichever party). In many cases they have been seen instinctively in the heart of government, in Whitehall, as either redundant or offensive. That has been the reality. This attitude has been in part based on arguments (or myths) about international competition that, in practice, can often best be responded to at the European level.

Jacques Delors triggered a remarkable shift in the attitude of the British trade union movement when he set out his vision of 'a people's Europe' and the idea of the Social Chapter at the 1988 TUC Congress, but the seeds of Social Europe had been sown much earlier. The European model of employment rights and social dialogue began with the need to restructure the coal and steel industries after the war. The European Coal and Steel Community brought trade unions and employers' organisations together in a tripartite organisation together with the embryonic European Commission. It received another boost in the 1960s with the establishment 
of eight sectoral social dialogue committees in agriculture, road transport, sea fishing, inland waterways, railways, footwear, coal and steel. The next phase of social policy began with a series of social directives like TUPE in 1977. These changes began a shift towards the European Community with a social element, workers' rights and a role for unions - a shift away from a simple free market. Delors' agenda led to a transformation in the attitude of the Labour Party and the TUC. Long suspicious of involvement in the 'capitalist club', the British labour movement embarked upon a period of positive engagement with the European institutions, exerting maximum influence on the EU law-making process.

That influence has been remarkably successful. The fact that we now have an EU directive setting out a general framework for information and consultation in firms employing more than 50 people can be traced directly to the introduction of the proposal for such legislation into the European Commission's work programme by officers of the TUC and British Labour MEPs, the ETUC and as well as by events at the former Renault plan at Vilvoorde, Brussels. The EU's corpus of health and safety laws was shaped to a considerable extent by amendments tabled by British Labour MEPs, but largely drafted by a ETUC network of trade union health and safety officers formed in the mid-80s. The wider labour movement could not be aware of this detail, of course, but there was a general sense that Europe was delivering for working people - indeed through much of the Thatcher and Major years, Europe was the only mechanism for delivering improved conditions for working people. Positive engagement has paid huge dividends over the last 15 to 20 years but we should not lose sight of improvements gained as a result of even earlier EU social and employment laws. The 1970s, for example, had seen the introduction of landmark EU-wide social laws governing, among others, collective redundancies, equal pay for work of equal value, and workers' rights in the event of the transfer of an undertaking or where insolvency occurs.

The fact that these laws are EU-wide and that they are the product of the EU law-making machine is very important to British workers. It is unlikely that such a body of law could have been introduced by any one nation acting alone. Equally important, the fact that they are EU laws means they deliver rights which will endure - member states cannot unilaterally repeal or weaken them as they can with their own laws (and which we witnessed close-up during the Thatcher years). Indeed, these laws are part of the 'acquis' which new member states have to apply when they join the EU and this has been very important in spreading social dialogue and collective bargaining in central and Eastern Europe. The measures represented by the TUC booklet's 12 examples cannot, of course, do more than make a modest contribution to removing all the significant causes of inequality and insecurity that persist in Britain. For example, our distribution of income and wealth is far more unequal than that of most other European economies - we are bunched with Greece, Spain and Portugal at the opposite end of the spectrum from the successful Nordic economies or the Netherlands, whose top 10 per cent of earners receive 24 per cent of the national total (after tax) whereas in Britain it is 36 per cent. We believe it would be timely for the British Government to acknowledge that it is not impotent in this, and commit itself to coming more into line with the income distribution in equally successful European countries. 


\section{Jobs and globalisation}

The growing sense of precariousness in working life has combined recently with a feeling in some quarters that Europe is adding to, rather than helping to tackle, the problem. For too many working people, the quality of their employment has been deteriorating rather than improving. The Lisbon process adopted by all of our leaders seven years ago promised to make Europe 'the most dynamic knowledge-based economy in the world with more and better quality jobs and greater social cohesion'. It was supposed to be delivered through a balanced policy mix of economic, employment and social policy. In reality, the economic pillar has dominated. There has been a failure to deliver promised measures to balance flexibility for businesses with security for workers. There is a perception that some in Europe are intent upon pursuing a deregulatory agenda. Suspicion surrounds the drive for better regulation. The fact that any of these employment and social laws could only be repealed if the Commission were to make such a proposal and the Parliament and full Council agreed to it (which is virtually impossible) does not diminish that fear.

So, just as there appears to be a slowing down on the social front, there seems to be a speeding up on the liberalising front. The recent prime example was the Services Directive - the directive designed to create an internal market for services. The 'country of origin' principle (the idea that the regulatory framework of the home country of a service provider will apply to the services they provide rather than the regulatory framework of the country they are working in) was quite rightly seen as a threat to existing standards, terms and conditions. The European Parliament accepted the trade unions' arguments on this point and voted 394 to 215 to amend the directive in its first reading in February 2006.

Some of these difficulties are a question of perception - such as the fear of deregulation. Others, such as the blocking of important social dossiers, are a fact. But they combine to produce an overall perception that some want to take us back 20 years, and the confusion they create means that Europe is perceived by some as caring only about economics and the market. We should put on record the continuing successes of joint work between MEPs and trade unionists, including successfully resisting attempts to use the revision of EU public tendering and procurement rules to assess best value only with reference to price. This will mean that environmental, social and employment considerations can also be taken into account. And, as mentioned earlier, enlargement of the EU to the east has meant that common European employment rights now cover many more millions of workers.

Working side by side across the ETUC and the European Parliament we have seen substantial results. Trade unionists can be justly proud of having campaigned for the improvement that the EU has made. This record of concrete achievements is in contrast with many political statements that are long on rhetoric but short on substance. The trade union movement, with the support of a majority of MEPs, has reacted strongly to neo-liberal rhetoric, as the huge ETUC-led demonstration in Strasbourg at the time of the vote on the Services Directive, and the even larger demonstration in Brussels a year earlier, show. Yet there is unfinished business and trade unionists across Europe need to work with others such as MEPs to go further. Progress towards social justice must not come to an end. 


\section{The 'Springtime of the Peoples'}

To understand the richness of the continental Social Model, only aspects of which have been sketched out here, it is necessary to go back to 1848 and the social revolutions that swept the continent at that time. Inheriting the 'rights of man' values of the 1789 French revolution they actually intersected with the Chartist movement in contemporary Britain. However, whereas the continental revolutions successfully established the nascent social model, in Britain the Chartists were brutally put down, as were early trade unions fighting for similar rights, like the mineworkers, in 1844. From then, Britain travelled alone, sending its fighting forces around the world in the great Imperialist age of Victorian conquest. Trade unions battled onwards, but never once managed to secure a fundamental social contract of the kind that was extended, inexorably across the European continent, eventually enfolding itself into the European Social Model, after World War Two. In truth, their objectives were usually more modest and never revolutionary.

There were attempts to build a social settlement and for 35 years after 1945, unions were powerful if decentralised and hampered by competing structures and political views. ILO standards in the 1920s and 1930s were prompted by the TUC and the UK Government. Tripartite structures were established including a National Economic Development Council and there were periods of agreed policies, leading to criticism from the Left (class collaboration) and from the Right (corporatism, anti-freedom). After a major round of chaotic strikes in 1978/79, these attempts were buried by Mrs Thatcher and have never been resurrected by the 'new' Labour governments.

To this day, the absence of such a framework in the UK means that British trade unions do not have the supporting legal and industrial relations framework to enforce adequately workers rights gained in recent decades in Brussels. Consequently, British trade union leaders can say both 'We want the same rights European workers have in law' and 'Europe is a capitalist club'! The fact that no recent government in the UK has been prepared to grant even a minimal structure of rights or a legal framework of national and sectoral social dialogue to British workers and has actually blocked the introduction of such measures via Brussels, has not recreated support for the European project among British trade union leaders. The fact that British governments - both Tory and Labour - have been leading supporters of the US neo-liberal economic model, which has plunged the global economy into such disaster, has not stopped British trade union leaders from resorting to what they know best, find most familiar - which is scrapping in an unhappy marriage with their 'Labour Movement' colleagues in the Labour Party leadership and viscerally attacking the Tories in opposition or in power. Thus the great game of the birth of British labour is played out incessantly.

The present period is characterised by a drift back to national competence in EU social policy, all the while that the European economy integrates still further. The very economic, integrating forces are creating a backlash in the social domain. Because the main inspiration for economic integration has always come from liberal economic policy, allied in a strange way with federalist ambitions and aspirations among a range of European politicians, it has a greater impetus. The social 
integrative mechanism has remained much less well-supported, by contrast. It has been the preserve of the Left and in German model countries the joint preserve of the Social Democrats and the Christian Democrats, who agreed a 'Rhineland Model' of capitalism to forestall any return to National Socialism. Even in Germany, this model is under pressure, as the EU level moves by contradictions and contrasting pressures, with the free market aspect dominant.

In comparison, the development of the EU Social Model has moved forward by watersheds - the first was the ECSC Consultative Committee of social partners; the second major advance was the European Workers Charter and the Social Action Programme (SAP) set up in parallel with the development of the Single Market and the third was the Maastricht Social Chapter procedure, granting European collective bargaining rights to the social partners. The SAP largely delivered its promises in its first phase, with the latter part of it being implemented through the Social Chapter procedures of social partner negotiation. These brought legally binding and voluntary agreements onto the stage of the European Social Dialogue. The legally binding agreements delivered millions of euros and pounds into the pockets of workers throughout Europe, especially through the equal treatment (including equal pay) clauses of the part-time and fixed term contract agreements, as they entered Member State law. A third Directive on Temporary Agency Work is imminent. Pay remains the proper preserve of national level collective bargaining, albeit some of it co-ordinated between trade unions in some countries for a while, as between the Benelux countries and Germany. British workers, being outside the Eurozone, did not benefit from these centrifugal forces, although part-timers and fixed term contract employees have benefited greatly, despite the UK Labour Government's rather minimalist implementation of the consequent directives into British law. Similarly, more British workers have benefited from the EU TUPE laws than any other national group because privatisation has gone furthest in the UK.

\section{New Labour in power}

It is illuminating - and from my viewpoint, dispiriting - how little the change of government to Labour from Conservative in 1997 made in social policy. It is not that there were no differences between the Conservatives and Labour and of course Labour ended the opt out from the Social Chapter of the Maastricht Treaty in 1997. But, de facto, the opt out was replaced by a commitment to the Confederation of British Industry (CBI) employers not to support specific measures to which the CBI were hostile and with one exception - information and consultation - that commitment has been kept.

Equally, it is interesting to note the continuity in the French government's position, regardless of who is in power. They are always the most active supporters of the ETUC and a 'more' Social Europe. Jacques Delors was from that French school. He had 'sold' a pro Europe line to the British Labour Movement in 1988 following his speech at the TUC on the grounds that a single market needed to be complemented by social measures to present a race to the bottom. So that there shouldn't be free competition across the single market on the basis of health and safety standards, including working hours; that there should be robust antidiscrimination measures on a range of issues; that what were then regarded as 
atypical workers much more typical today - should receive equal treatment to regular workers as far as possible; that there should be a Europe-wide commitment to information and consultation with workers' representation before major changes including establishing European Works Councils in multinational companies. Those messages were enthusiastically embraced by Labour in order to dump antiEuropeanism. But, in truth, they were dumped when that was achieved.

For me a personal low point was when a UK government instructed barrister turned up in the Laval case at the European Court of Justice to argue that the right to strike is not a fundamental right. Is that what a Labour Government is for? I cheered up a little when that particular point was lost before the Court. However recent decisions in the ECJ - Viking, Laval, Rueffert and Luxembourg - all of which asserted the pre-eminence of the single market over fundamental union rights - are causing great concern. For most trade union leaders of large TUC unions, the clear gains made by part-timers and other atypical workers have been peripheral. Their bitterness at the wrecking moves of their own Party in power of EU legal rights, such as the specific exclusion of British workers from the Charter of Fundamental Rights, has sunk deep and produced, not a fight back at European level, through the ETUC, but a focus on national politics and its very uncertain rewards. There is a tendency too to fall back onto demands for international or global trade union solidarity and the ILO system of rights, despite these being primarily 'gentleman's agreements' without real legal impact.

In response to the loss of union defences in legal worker rights and collective bargaining cases before the European Court of Justice, a national response may now be setting in. The phenomenon of 'cutting your nose off to spite your face' is beginning - with moves to withdraw support from the Lisbon Treaty, for example, unless new international, cross-border collective bargaining rights are implemented in EU law. This is not just in the UK - it is Europe-wide, a feeling that trade union legal freedoms are back were they were 100 years ago. We are campaigning for change and to stop the trend towards isolation.

This would be a serious mistake - it would be isolationist in practice, even if the rhetoric is often internationalist. For the ETUC it simply must not occur. Social progress in Europe moves ahead by watersheds, while economic integration proceeds inexorably with the pressure of capitalist development. No European country can stand alone in the global market place, not even Germany - as the global economy marches on. Even environmental action is so closely linked into economic policy now that it is easier to implement - as in the Emissions Trading Scheme - than social policy. Increasing numbers of trade union leaders and political party leaders believe that national level social policy can be sufficient - either because they believe they can win the argument more easily for local protection, or because, as economic liberals they want to pull the EU social policy's teeth and repatriate social policy to national level. This tendency ignores the fact that the UK's model of financial capitalism (with much less emphasis on manufacturing than the large continental countries and much more emphasis on debt) is especially vulnerable in the recession. 


\section{With the financial crisis, another watershed for social policy}

While it is the deep financial and growing economic shock which has changed the only game in town, it also changes the whole framework for trade union action. There can be only one question now to be answered for European and British trade unions alike, as well as those others all over the world: what is the nature of the New Deal that we want? How can we mobilise to get it, not in Britain (impossible alone) but in Europe, in North America, in Asia-Pacific? The economic contagion is now buried deep in the world's financial infrastructure and it is unlikely that even regions like the EU can hope to purge it from its institutions. What we need is a Rooseveltian New Deal of a new and deeper type, albeit taking some lessons from precedent. What we need is to build a similar coalition of those who where there for Roosevelt. This can be done in the EU, it cannot be done easily in the UK.

How is the ETUC going to develop that, with its international counterparts: that is the real question for British trade unions. The following statement, issued by the ETUC, at the September 2008 Summer School of trade union leaders is just our first step:

The world financial crisis must be a turning point and cause a complete change in the way the financial world works. The dominant model of financial capitalism is close to collapse. This capitalism, liberated from long-standing restraints around 25 years ago, especially in the USA, has been used since as a role model for the rest of the world to follow. It has patronised the many while it exploited them for the benefit of the few, following years of exalting privatisation, deregulation and unfettered markets.

Now its excesses have brought it close to ruin - and it threatens the real economy. Indeed Europe's economy lives in fear of being hit by a financial tsunami speeding across the Atlantic despite the relative strength so far of the euro area. The US Government is scrambling together hundreds of billions of dollars to save key banks from their own folly; the credit crunch is strangling finance for industry as banks hoard money to protect themselves. Recession looms.

Let us be absolutely clear. This crisis was caused by greed and recklessness in Wall Street, London and other major financial centres. Senior executives permitted speculation on a huge scale on investments they ill understood. Speculators have exacerbated the serious rises in fuel, food and raw materials. The losers are many and include workers in the industry and more generally, pensioners, families, providers and firms seeking investment capital, and all of us as taxpayers bailing out banks. The costs of the American rescue are huge and the commitment of central banks round the world has already been very substantial. It will take years to recover the money, if ever we manage to do so, and our future ability to fund high-quality public services is being placed in jeopardy. 
That's why this time there must be a turning point. Never again can irresponsibility by banks and hedge funds and the rest be allowed to come close to bankrupting nations. Never again must taxpayers' money be used to prop up institutions that continue to pay huge salaries and bonuses to their top executives. Never again can shareholder value, with directors' bonuses linked to it, be allowed to be the sole goal of companies. We cannot risk a repeat of this gross irresponsibility, greed and negligence.

The ETUC is working with the International TUC, UNI-Europa representing finance industry workers and others on a trade union response to this crisis, but it is already clear to us that there need to be:

* injections of public money into financial institutions that carry with them public influence and control so causing a fundamental change in behaviour;

* much tighter control of financial institutions' ability to leverage their operations, by strengthening the ratios of solid assets to liabilities;

* an international, certainly European, level of effective regulation. This is necessitated by the scale of global financial capitalism which now transcends most individual nations. A European Ratings Agency is necessary;

* government action to ensure that funds are available for investment in the real economy, helping develop green jobs and technologies and sustainable development;

* help provided for workers affected, for householders threatened by eviction, for pensioners threatened with poverty in old age, for entrepreneurs seeking investment capital. It is not fair that the main beneficiaries might be those who caused the mess;

* a European-level response to the slowdown that is unfolding in the real economy to prevent the financial turmoil intensifying further as well as to avoid a return to the 'beggar-my-neighbour' approach of competitive wage moderation and reductions in social protection which harm workers and their families; and

* urgent return of public policy attention to the major issues of income and wage inequalities. It is inequality and poor wage income for ordinary workers that are driving households into ever more debt through risky financial market techniques.

The ETUC therefore calls on Europe to fight for workers' rights, for fair and decent wages, for stable jobs and for strong collective bargaining practice, independent of and not subordinated to law courts and judges.

\footnotetext{
${ }^{2}$ Statement by the European Trade Union Confederation (ETUC) on the crisis of Casino Capitalism 27 September 2008, London.
} 


\section{The best way forward?}

'Socialism in one country' was long the call of the British Communist Party and some trade unions. It was never viable and it is not now. The fact is that among the world's larger countries the UK is uniquely open to foreign ownership and investment. There are no calls for British sovereign wealth funds, as President Sarkozy has suggested in France. National solutions cannot be the whole answer and while the same could be said for European solutions, the fact remains that the EU is one third of the world's economy. Influence Europe and you can influence the world.

So for the future, my personal hope is that British unions, the oldest in the world, come again to see that the main routes to growth and influence are through active and positive engagement in the European Union. It may be overstating things today to claim it as the 'only' game in town. But it is the main game. If out of the wreckage of the financial economy the UK is to move more in the direction of a genuine social market economy with a strong welfare state, public services and widespread collective bargaining, then the European route offers the most promise. Retreating into nationalism offers little except playing into the hands of the far right. British unions have a justifiably proud record of action against the far right with no compromises made. But constructive action in Europe with similar sized economies, with similarly minded approaches in the part of the world where unions are the strongest, this is the best way forward. The fight for a Social Europe must go on. 